\title{
Fiber-enriched calcium phosphate cement implanted in the femur of rats: a histological evaluation
}

\section{Cimento de fosfato de cálcio reforçado por fibras implantados nos fêmures de ratos: uma avaliação histológica}

\author{
Taiane Coutinho de Oliveira* \\ Marcos Antonio Torriani* \\ Adriana Etges ${ }^{* * *}$ \\ Roger Correa de Barros Berthold ${ }^{* * * *}$ \\ Thiago Aragon Zanella**** \\ Cláiton Heitz*
}

\begin{abstract}
Objective: to perform a histological analysis of nylon, carbon, and polypropylene fiber-enriched calcium phosphate cement (CPC) for use as bone substitute in the femur or rats. Materials and method: Fiber-enriched CPC blocks (6-mm diameter, 2-mm thickness) were implanted in the femur of 20 male Wistar rats. The animals were euthanized at 30, 60, 90, and 120 days, with removal and histological assessment of specimens. Results: Biocompatibility, resorption, and osteoconduction were assessed. At all times, histological assessment revealed the formation of dense connective tissue with low cellularity, little vascularization, and a few mononuclear cells. Surrounding the implant, slight resorption and hyalinization of peripheral collagen fibers were observed, with evidence of incorporation of implant material into connective tissue. Osteoid tissue was observed at 120 days. Bone resorption surrounding the implant was not significant. Conclusion: Based on the present criteria, CPC seems adequate for use as bone substitute.
\end{abstract}

Keywords: Biomaterials. Bone substitutes. Calcium Phosphate Cements.

\section{Introduction}

Many surgical procedures involving bone tissue, such as enucleation of cysts, excision of tumors, and tooth extraction, as well as treatment of chronic inflammatory processes, fractures, and the aging process, lead to the loss of calcified structures and to the formation of intraosseous space $^{1,2}$. As a result, much research has been performed in search of alternatives to recover and/or maintain bone volume and quality in addition to adequate contours ${ }^{3}$. One example is the research on calcium phosphate cements, which have been extensively studied in the past years due to their potential suitability for biomedical applications $s^{4,5}$. Resistant, biocompatible materials such as calcium phosphate are extremely valuable; autografts, which are still widely employed with the aim of preventing an adverse immune reaction, have limitations associated with the location and size of bone defect, in addition to disadvantages such as the need for a second surgical intervention to remove the graft, postoperative

PhD in Dentistry, Department of Dentistry, Federal University of Pelotas, Rio Grande do Sul, Pelotas, Brazil.

$\mathrm{PhD}$ in Oral and Maxillofacial Surgery, Department of Oral and Maxillofacial, Surgery, Pontifical Catholic University of Rio Grande do Sul, Porto Alegre, Brazil. PhD in Oral Pathology, Department of Pathology, University of São Paulo, São Paulo, Brazil.

**** Master student of Oral and Maxillofacial Surgery, Department of Oral and Maxillofacial Surgery, Pontifical Catholic University of Rio Grande do Sul, Porto Alegre, Brazil.

***** Postgraduate student of Oral and Maxillofacial Surgery, Department of Oral and Maxillofacial Surgery, Pontifical Catholic University of Rio Grande do Sul, Porto Alegre, Brazil.

****** Chairman and Professor, Department of Oral and Maxillofacial Surgery, school of Dentistry, Pontifical Catholic University of Rio Grande do Sul, Porto Alegre, Brazil. 
complications, increased surgical time, difficulty in shaping the graft in the adequate form, and in some cases, unavailability of the necessary amount of bone $e^{6,7}$.

As stated by Santos $^{3}$ (2002), calcium phosphate cements have many advantages when used for filling and replacement of bony defects: cement may be shaped during the surgical procedure, thus shaping prior to implantation is not necessary; excellent contact between bone and implant; biocompatibility; and bioactivity. A disadvantage of pure calcium phosphate cement is its low resistance, limiting its applicability. To address this limitation aiming to increase the material's mechanical resistance and tenacity while maintaining its advantageous properties, in 2002 Santos developed a double-setting calcium phosphate cement (CPC) by adding to the traditional cement an in situ polymerization system with carbon, propylene, and nylon fibers, which provided an increase of $150 \%$ in mechanical resistance. The propylene and nylon fibers employed to enrich calcium phosphate are commercially available and commonly used in the clothing industry. Carbon fibers are employed in the manufacture of aircrafts ${ }^{3}$. Adding fibers to calcium phosphate increases the ability to absorb impact. Loads are transferred through the matrix onto the fiber, increasing resistance.

Based on these principles, the aim of the present work was to assess the histological behavior of nylon, carbon, and propylene fiber-enriched calcium phosphate cement blocks implanted in the femur of rats, examining biocompatibility, osteoconductive capacity, and resorption.

\section{Materials and method}

The study protocol was approved by the Animal Experimentation Ethics Committee at the Federal University of Pelotas, Brazil, and by the Ethics and Science Committee at the Catholic University School of Dental Medicine (PUCRS), Brazil.

Twenty 3 month-old male Wistar rats (Rattus novergicus) weighing $300 \mathrm{~g}$ were divided into four groups containing five animals each for assessment at $30,60,90$, and 120 days. All were submitted to the same surgical procedure, in which nylon, carbon, and polypropylene fiber-enriched calcium phosphate cement blocks (diameter $6 \mathrm{~mm}$, thickness $2 \mathrm{~mm}$ ) were implanted in the animal's femur.

\section{Surgical procedure}

General anesthesia was induced with intraperitoneal injection of $20 \mathrm{mg} / \mathrm{kg}$ tiletamine hydrochloride associated with zolazepam hydrochloride (Zoletil $50^{\mathrm{TM}}$ Virbac do Brasil Indústria e Comércio Ltda, São Paulo, SP, Brazil). After shaving and antisepsis, a continuous incision of approximately $2 \mathrm{~cm}$ was performed along the entire extension of the skin next to the right femur. Subcutaneous and muscle tissues were divulsed, providing direct access to the exposed femoral diaphysis.

The fiber-enriched CPC block was implanted on the cortical bone and fixed with a 5-mm long Promm $^{\text {TM }} 1.5$ titanium microscrew (Fig.1). Next, the skin was sutured with a 4-0 nylon thread. The animals were euthanized $30,60,90$, and 120 after the surgery with intraperitoneal injection of a lethal dose $(50 \mathrm{mg} / \mathrm{kg})$ of tiletamine hydrochloride with zolazepam hydrochloride (Zoletil $50^{\mathrm{TM}}$ ).

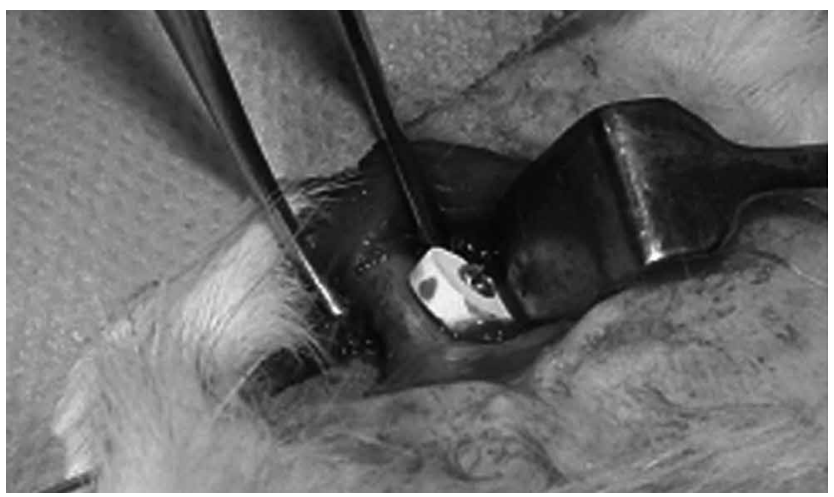

Figure 1 - View of CPC block fixation in the femur of rats.

\section{Preparation of specimens}

After fixation with $10 \%$ buffered formalin $(\mathrm{pH}$ 7.0) for $24 \mathrm{~h}$, the specimens, made up of bone and soft tissue, were shaken in ambient temperature with $5 \%$ nitric acid solution for decalcification and processed for microtomy section into $5 \mu \mathrm{m}$ slices. In each specimen, the first slice showing bone and soft tissue plus fragments of the cement block was selected.

The selected slices were stained with hematoxylin and eosin. Microscopic analysis and histological description of the femoral sections and adjacent soft tissue were carried out with an optical microscope at 40X, 100X and 400X magnification.

To evaluate the results, a qualitative descriptive analysis was performed by one of the authors (T.O.), and calibrated by a pathologist. The following aspects were assessed: tissue density, vascularization and cellularity of connective tissue, type and density of inflammatory infiltrate, implant resorption, and osteoconduction.

\section{Results}

The characteristics of the repair process were similar at all times. At 30 days, histological analysis revealed the formation of dense connective tissue, with low cellularity, little vascularization, and a few mononuclear cells. Small resorption areas were observed around the implant, in addition to hyalinization 
of peripheral collagen fibers. Implant material was observed to be incorporated into the tissue (Fig. 2).

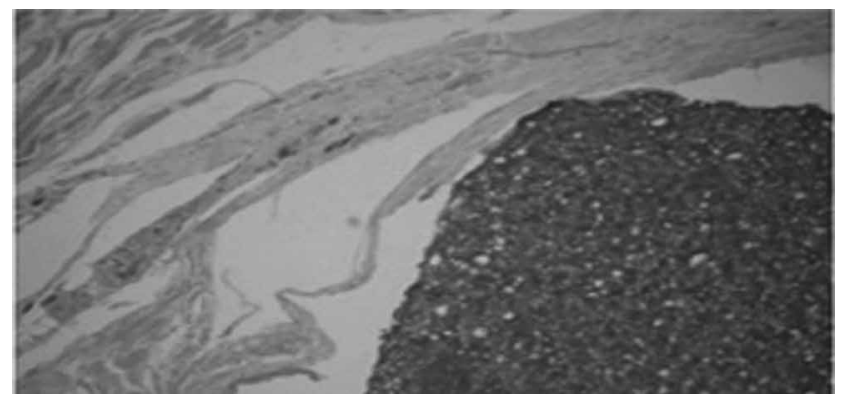

Figure 2 - Dense connective tissue with little vascularization and cellularity, and incorporated implant material (200X).

At 60 days again we observed dense connective tissue with limited vascularization surrounding the implant, with hyalinization of peripheral collagen fibers (Fig. 3). At 90 days, in addition to slight vascularization and cellularity in dense connective tissue with hyalinization of peripheral collagen fibers, there were gaps indicating implant resorption (Fig. 4). The same features were observed at 120 days (Fig. 5). Also, histological analysis at 120 days suggested the formation of osteoid material and incorporation of exogenous material (implant) into the newly formed tissue, which was closely apposed to the implant and adjacent bone (Fig. 6 and 7).

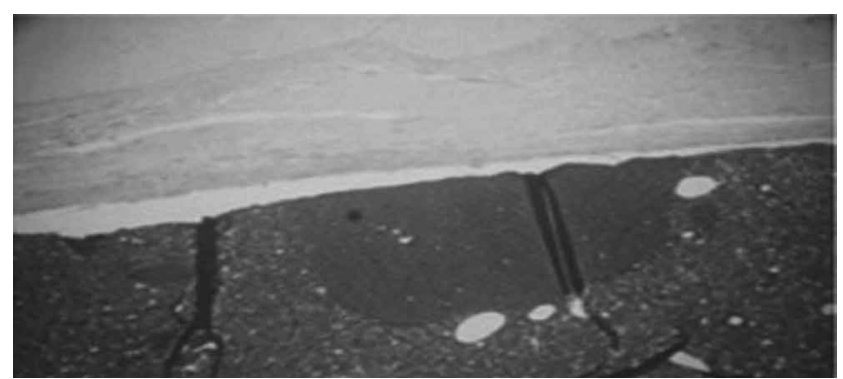

Figure 3 - Intense hyalinization of collagen fibers surrounding implant (200X). Gaps resulting from resorption of implant material.

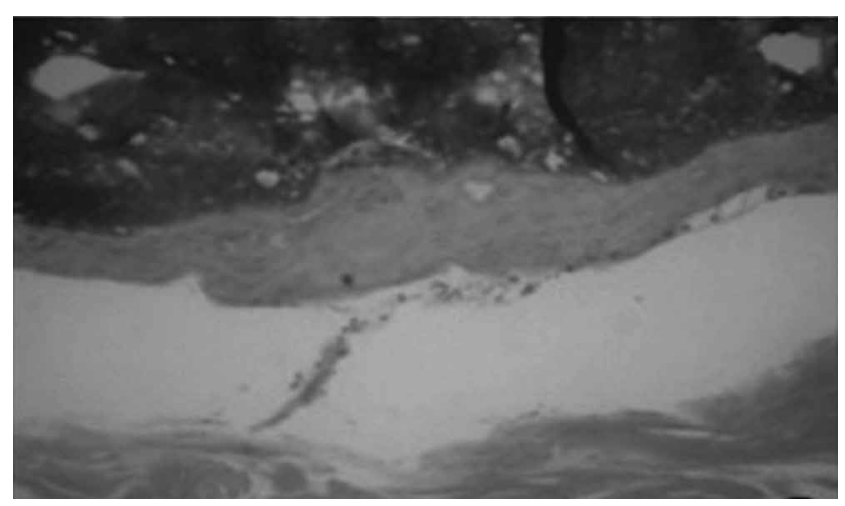

Figure 4 - 400X, gaps indicating implant resorption.

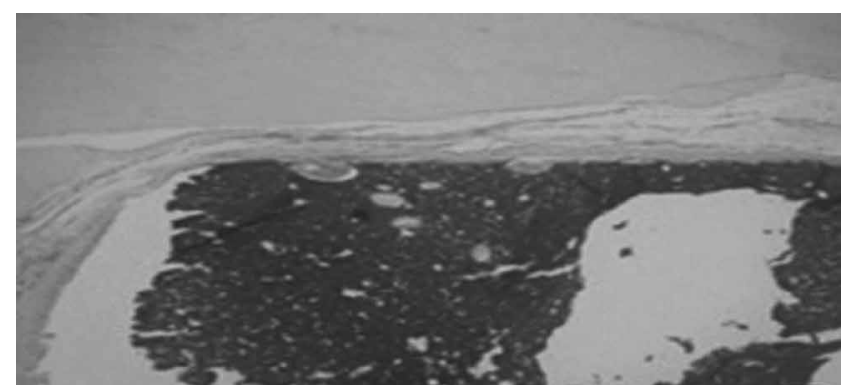

Figure 5 - 100X. Incorporation of implant material can be clearly observed next to the dense connective tissue, suggesting bone neoformation.

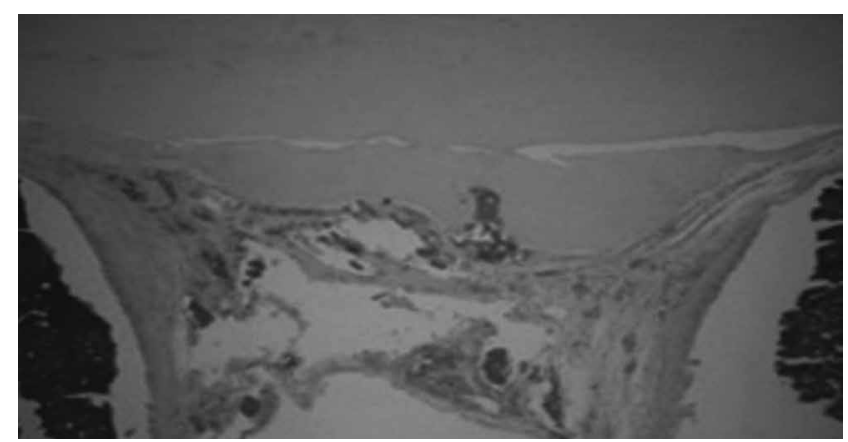

Figure 6 - 100X. Formation of osteoid material and incorporation of exogenous material (implant) into the newly formed tissue.

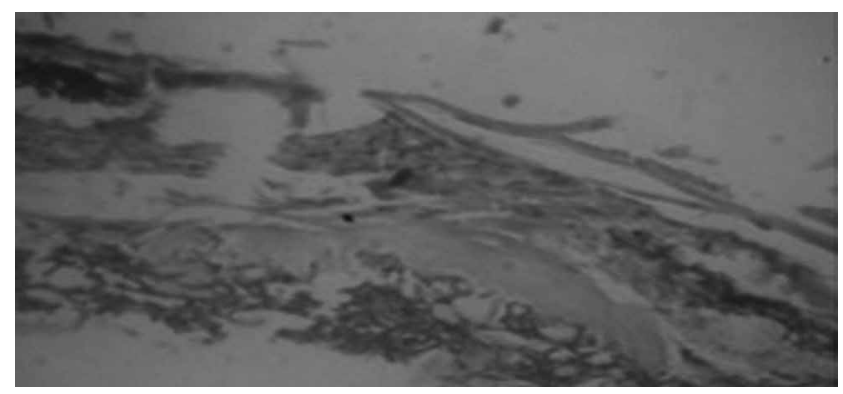

Figure 7 - 400X. Formation of osteoid material and incorporation of exogenous material (implant) into the newly formed tissue.

\section{Discussion}

The present results indicate that CPC is biocompatible, as described by $\operatorname{Santos}^{3}(2002)$. That means that the material and any possible degradation byproducts are well tolerated by surrounding tissues without short or long-term harm to the organism ${ }^{1}$.

In addition to being biocompatible, implants should immediately and adequately enable the performance of the specific function (both static and dynamic) of the tissue being replaced - a characteristic that is at the core of the concept of biofunctionality ${ }^{8}$. This concept also incorporates the problems associated with chemical degradation of materials, given that the physiological environment can be very aggressive, even to materials considered to be extremely chemically inert, leading to reduction of implant efficiency ${ }^{9,10}$.

Concerning the permanence vs. resorption of the material from 30 to 120 days, giant cells acting on the surface were not observed in any of the groups, 
which explains the low rate of material degradation, appearing as small resorption areas at implant borders ${ }^{11,12}$. These resorption areas were practically insignificant however, without reduction of implant volume. Osteoconduction represented by bone neoformation surrounding the implant at 120 days is suggested by the presence of osteoid material, especially in areas close to the preexisting bone.

In 2005, Xu and Simon $^{9}$ (2005) discussed the low resistance of calcium phosphate, suggesting that this material was only suitable for applications not requiring strength. Those authors also point out that the absence of macroporosity might hinder cellular infiltration, bone development, and fixation of the implant. The material we employed in this study presents macroporosity, which may facilitate these aspects. Strength was not analyzed in the present study.

We observed favorable characteristics of CPC, such as excellent contact between bone and implant, and low degradation, along with biocompatibility and bioactivity, demonstrated by the discrete initial mononuclear inflammatory response, absence of infiltrate at 120 days, and evidence of osteoid material formation.

The presence of osteoid material at 120 days indicates bioactivity in the material tested. It should be noted that bioactivity is considered in the presence of chemical connection between the material and bone tissue (osseointegration). The chemical similarity between some materials and the mineral portion of bone allows bone tissue to bond to these materials, promoting osteoconduction ${ }^{13}$. The main materials in this class are glasses and calcium phosphate or glass-modified hydroxyapatite ceramics and calcium phosphate composites ${ }^{3}$. There is a growing need for experimental studies using fiber-enriched CPC to test the characteristics and behavior of this material in the long term.

\section{Conclusion}

In summary, fiber-enriched CPC was observed to be biocompatible in the present study, and did not present significant difference in terms of inflammatory infiltrate from 30 to 120 days, indicating the applicability of this material in vivo. The low rate of resorption at the end of 120 days shows that CPC is stable as a bone substitute, and suggests that a bone matrix was formed surrounding the implant and close to the preexisting bone, indicating osteoconduction. Despite the need for further studies, taking into consideration the parameters and limits of the present experiment, it is also possible to affirm that fiber-enriched CPC in the form of prefabricated blocks may be an adequate implant and bone substitute.

\section{Resumo}

Objetivo: O objetivo foi realizar a análise histológica do cimento de fosfato de cálcio (CFC) enriquecido por fibras de nylon, carbono e polipropileno, usado como substituto ósseo em fêmures de ratos. Materiais e método: Blocos de CFC enriquecidos por fibra (6- $\mathrm{mm}$ diâmetro, 2-mm de espessura) foram implantados nos fêmures de 20 ratos Wistar. Os animais foram eutanasiados com 30, 60, 90 e 120 dias, com remoção e avaliação histológica dos espécimes. Resultados: Foram avaliadas a biocompatibilidade, a reabsorção e a osteocondução. Em todos os momentos, a avaliação histológica revelou a formação de tecido conjuntivo denso com baixa celularidade, pouca vascularização e poucas células mononucleares. Ao redor do implante foi observada pouca reabsorção e hialinização das fibras de colágeno periféricas, com evidência de incorporação do material do implante para o tecido conjuntivo. Tecido osteoide foi observado com 120 dias. Reabsorção óssea ao redor do implante não foi significativa. Conclusão: Baseado no critério presente, CFC parece adequado para uso como um substituto ósseo.

Palavra-chave: Biomateriais. Substitutos ósseos. Cimento de Fosfato de Cálcio.

\section{References}

1. Peterson LJ, Peterson TEM, Ellis III E, Hupp JR, Tucker MR. Reparação das feridas. In: Hupp JR, editor. Cirurgia oral e maxilofacial contemporânea. 3.ed. Rio de Janeiro: Guanabara Koogan; 2000. p. 57-67.

2. Roberts WE, Garetto LP. Fisiologia e metabolismo ósseos. In: Misch CE, editor. Implantes dentários contemporâneos. 2.ed. São Paulo: Editora Santos; 2000. p. 225-37.

3. Santos LA. Desenvolvimento de cimento de fosfato de cálcio reforçado por fibras para uso na área médico-odontológica [Tese de Doutorado]. São Paulo: Faculdade de Engenharia Mecânica, Universidade Estadual de Campinas; 2002

4. Prolo DJ, Rodrigo JJ. Contemporary bone-graft physiology and surgery. Clin Orthop Relat Res 1985; (200):322-42.

5. Driessens FCM, Boltong MG, Bermúdez O, Planell JA, Ginebra MP, Fernández E. Effective formulations for the preparation of calcium phosphate bone cements. J Mater Sci Mater Med 1994; 5(3):164-70.

6. Constantino PD, Friedman CD. Soft tissue augmentation replacement in the head e neck: general considerations. Otolaryngol Clin North Am 1991; 27(1):1-12.

7. Muting E, Mirtch A, Lemaitre J. Bone repair of defects filled with a phosphocalcic hydraulic cement an in vivo study. J Mater Sci Mater Med 1993; 4(3):337-44.

8. Ravaglioli A, Krajewski A. Bioceramics materials, properties, applications. New York: Chapman \& Hall; 1992.

9. Xu HHK, Simon Jr. CG. Fast setting calcium phosphate-chitosan scaffold: mechanical properties and biocompatibility. Biomaterials 2005; 26(12):1337-48.

10. Dos Santos LA, Carrodéaguas RG, Boschi AO, Arruda AC. Fiber-enriched double-setting calcium phosphate bone cement. J Biomed Mater Res. 2003; 65(2):244-50. 
11. Banthia N, Dubeau S. Carbon and steel microfiber-reinforced cement-based composites for thin repairs. J Mater Civil Eng 1994; 6 (1):88-99.

12. Hirayama S, Takagi S, Markovic M, Chow L. Properties of Calcium Phosphate Cements With Different Tetracalcium Phosphate and Dicalcium Phosphate Anhydrous Molar Ratios. J Res Natl Inst Stand Technol 2008; 113(6):311-20.

13. Huan Z, Chang J. Calcium-phosphate-silicate composite bone cement: self- setting properties and in vitro bioactivity. J Mater Sci Mater Med 2009; 20(4):833-41.

\section{Corresponding author:}

Roger Correa de Barros Berthold

Pontifical Catholic University of Rio Grande do Sul (PUCRS)

School of Dentistry / Block 6

Av. Ipiranga, 6681

90616-900 Porto Alegre / Rio Grande do Sul

Phone: 555133203562

E-mail: rogerberthold@hotmail.com

Recebido: 06/11/2013. Aceito: 03/05/2014. 